\title{
THE CULTURE OF THAHÂRAH IN THE CORONA VIRUS PENDEMIC: An Offer to Prevent the Spread of Covid-19 with Islamic Jurisprudence Approach
}

\author{
Zurifah Nurdin \\ State Institute for Islamic Studies (IAIN) Bengkulu, Indonesia \\ Jl. Raden Fatah, Pagar Dewa, Bengkulu \\ E-mail: zurifah@iainbengkulu.ac.id
}

\begin{abstract}
Islamic teachings explain comprehensively how to purify, clean the body and the environment from uncleanness, and to use water and other washing media in a measured manner. In the concept of Islamic theory, this purification activity is known as thahârah. Due to the wide transmission of the Corona Virus Disease 2019 or Covid-19 throughout the world, this article offered preventive measures to restrain the spread of Covid-19 by practicing thahârah consistently based on a figh perspective. This study employed literary research method which traced a number of books by Islamic scholars related to the thahârah or purification procedures. After the data was collected, the analysis was carried out by analyzing, processing, and interpreting the data into a conclusion. The results revealed that in addition to eliminating hadats, dirt, and impurity, thahârah activities such as wudhu, tayamum, ritual bathing, and teeth brushing benefit for physical and spiritual health. If thahârah is practiced consistently; as a cleaning up routine activity, it will diminish the spread of Covid-19. Instead of just washing hands, for instance, it is recommended to do wudhu even if it is not for praying. Viruses sticking to the hands and face will be washed away and disappear if a person performs wudhu properly according to the teachings of the Prophet Muhammad. The research has shown that wudhu contains tremendous benefits for health as it can stimulate energy in the body and improve blood circulation.
\end{abstract}

Keywords: thahârah; Islamic jurisprudence; health protocol; prevent; spread of covid-19.

\begin{abstract}
Abstrak: Ajaran Islam secara rinci menjelaskan bagaimana bersuci, membersihkan badan dan lingkungan dari najis, dan bagaimana menggunakan air dan media pencuci lainnya dengan terukur. Aktivitas bersuci tersebut dalam konsep Islam disebut thahârah. Sehubungan dengan telah menyebarnya virus Corona 2019 atau Covid-19 yang melanda ke seluruh dunia, artikel ini menawarkan upaya tindakan preventif pencegahan tertularnya Covid-19 dengan membudayakan thahârah secara konsisten berdasarkan perspektif fikih. Penelitian ini menggunakan metode literary research, yakni menelusuri sejumlah buku-buku karya ulama Islam yang berhubungan dengan thahârah atau tatacara bersuci menurut fikih Islam. Setelah data terkumpul, dilakukan analisis dengan mengkalisifikasi, mengolah, dan menginterpretasi data menjadi suatu kesimpulan. Dari hasil analisis tersebut dapat disimpulkan bahwa selain bertujuan menghilangkan hadas, kotoran, dan najis, kegiatan thahârah seperti wudhu, tayamum, mandi, dan bersiwak bermanfaat untuk kesehatan jasmani dan rohani. Jika aktivitas thahârah ini dibudayakan secara konsisten, dalam arti dijadikan aktivitas yang rutin dalam membersihkan sesuatu, penyebaran Covid-19 akan tertekan menjadi minimal. Daripada mencuci tangan saja, misalnya, lebih baik sekalian berwudhu walaupun tidak untuk melakukan salat. Virus yang menempel di tangan dan wajah akan terbasuh dan lenyap jika seseorang melakukan wudhu dengan benar sesuai dengan ajaran Nabi Muhammad Saw. Penelitian membuktikan bahwa wudhu mengandung manfaat yang besar bagi kesehatan karena mampu merangsang dan menstimulus energi dalam tubuh serta melancarkan peredaran darah.
\end{abstract}

Kata kunci: thahârah; fikih; protokol kesehatan; pencegahan; penyebaran covid-19.

\section{Introduction}

To prevent the spread of the Corona Virus Disease 2019 or Covid-19, the government is very aggressively making appeals and a series of anticipations for the spread of the virus that came from Wuhan'. Among the government's

1 "SE MENDAGRI PENCEGAHAN PENYEBARAN COVID-19 pdf.Pdf," Google Docs, accessed October 21, 2020, https:// drive.google.com/file/d/1Ev_3qrgeA8i1k6iF-zAKnFs4MHBtvULX/ preview?usp=embed facebook. 
appeals, it became known as 3M, namely memakai masker (wearing masks), menjaga jarak (keeping your distance), and mencuci tangan (washing your hands). ${ }^{2}$ In addition, more complete anticipatory efforts are (1) washing hands with running water and soap as often as possible, (2) consuming nutritious foods, (3) eating more vegetables and fruits, (4) keeping physical distancing, (5) avoiding large crowd places, (6) and always wearing a mask. $^{3}$

The Indonesian government through the interior minister responded to the handling and prevention of the spread of Covid-19 by making a binding rule to the public. On the basis of central government regulations, almost every local government makes regulations on the prevention of Covid-19 so that people maintain "health protocols". The procedure to keep the spread of the corona virus is campaigned and socialized to all levels of society.

In the Islamic concept, the application of health protocol in order to minimize the spread of Covid-19 can be studied through the concept of thahârah. If these Muslims obey and are consistent with the rules of thahârah as taught by Allah

2 Anastasia lilin Yuliantina, "Tak Bisa Ditawar, Yuk Mencegah Dan Menekan Penyebaran Virus Corona Dengan 3M," accessed October 21, 2020, https://kesehatan.kontan.co.id/ news/tak-bisa-ditawar-yuk-mencegah-dan-menekan-penyebaranvirus-corona-dengan-3m.

3 Dalinama Telaumbanua, "Urgensi Pembentukan Aturan Terkait Pencegahan Covid-19 di Indonesia," QALAMUNA: Jurnal Pendidikan, Sosial, dan Agama, vol. 12, no. 01 (March 21, 2020), pp. 59-70, https://doi.org/10.37680/qalamuna.v12i01.290. preventive measures against these types of infectious diseases are mandatory as soon as possible. Indonesia as a nation of law, the prevention of infectious diseases is mandatory to be formed in a rule or regulation. The urgency of forming rules related to the prevention of Covid-19 is obliged to be formed in government regulation and regulation of the Minister of Health because both regulations are the implementation rules of Law No. 6 of 2018 concerning Health. Based on the author's analysis, there are 5 government regulations that must be established in order to perform countermeasures and prevention of infectious disease threats such as Covid-19 and there are 11 mandatory ministerial health regulations that are required to be established In anticipation of the Covid-19 threat. Both types of regulations are very useful in anticipating health emergency that ultimately leads to the health of Indonesian people. It is expected that both of rules can be made immediately in order to give legal certainty in preventing the spread of Covid-19 widely.","container-title":"QALAMUNA: Jurnal Pendidikan, Sosial, dan Agama","DOI":"10.37680/ qalamuna.v12i01.290",'ISSN":"2656-9779, 1907-6355","issue":"o 1","journalAbbreviation":"QLMN",'”language":"'id","page":"5970","source":"DOI.org (Crossref and His prophet, Muhammad PBUH, physical and environmental cleanliness will be maintained properly. This is because in thahârah there is not only a physical health dimension, but also a nonphysical health dimension such as mu'amalah, faith, worship, and morals. ${ }^{4}$

Thahârah etymologically means cleansing or cleansing oneself sensually from all kinds of dirt. In simple terms, thahârah is removing hadats and unclean something. 5 According to Muslim scholars, the meaning of thahârah in terms is doing something for which we may pray. ${ }^{6}$ This thahârah form is like ablution, bathing, tayamum, and eliminating uncleanness.

Drawing on the ongoing Covid-19 epidemic, Muslims should apply a clean way of life according to the teachings of tahârah which have been described in such detail by the Quran, hadith[s], and figh scholars. Some figh scholars make this chapter of thahârah always at the beginning of the discussion before describing other parts of figh. The book of Fathul Qarîb, for instance, puts the thahârah chapter at the beginning of the discussion?. This is because thahârah is the key in carrying out worship. ${ }^{8}$

As a form of anticipation for the spread of Covid-19, it would not be an exaggeration to have an offer to live a clean life with the concept of thahârah. An offer like this was actually initiated by the Pariaman city government of West Sumatra with the concept of "the thahârah Genius movement". 9 It's just that the Pariaman regional government movement was not responded to by other regions to be followed, even more so that it was practiced.

4 Mohammad Shodiq Ahmad, "Thaharah: Makna Zawahir Dan Bawathin Dalam Bersuci (Perspektif Studi Islam Komprehensif) ," Mizan: Journal of Islamic Law, vol. 2, no. 1 (2014), p. 26, https://doi.org/10.32507/mizan.v2i1.134.

5 Ibnu Abdullah, Fiqih Thaharah: Panduan Praktis Bersuci, (Pustaka Media, 2018), p. 13.

${ }^{6}$ Ibnu Qasim al-Gazi, Fath Al-Qarîb al-Mujîb, (Egypt: Musthafa al-Bab al-Halabi, 1925), p. 3.

7 Ibnu Qasim al-Gazi, Fath Al-Qarîb al-Mujîb..., p. 3.

${ }^{8}$ Muhammad Jawad Mughniyah, Fiqih Lima Mazhab: Ja 'fari, Hanafi, Maliki, Syafi 'i, Hambali (Gold Edition) (Shaf, 2015), p. 31.

${ }_{9}^{9}$ Rahmah Al Tiara, "Antisipasi Covid-19, Pemko Pariaman Gelar Program Thaharah - Portal Berita Editor," accessed October 12, 2020, http://www.portalberitaeditor.com/antisipasicovid-19-pemko-pariaman-gelar-program-thaharah/. 


\section{Method}

This study uses a qualitative approach by extracting data from sources of thought written in books. This study is a type of literary research. In social, religious, and humanities research, Silalahi revealed that literature research is a method that is often used ${ }^{10}$. Extracting data regarding the concept of thahârah and efforts to prevent the spread of Covid-19 was traced through an analysis of the thoughts of Islamic figures found in Arabic and non-Arabic language book sources. For this reason, this type of qualitative research is exploratory in nature, in contrast to quantitative research which is measuring and describing."

The source of the book examined in this study is Ahmad bin Husain's Fath al-Qarîb al-Mujîb which is better known as Abu Syuja 'and his Hasyiyah entitled Hâsyiyah al-Bajûri' ala Syarh al-'Allâmah Ibn Qâsim 'Ala Matni Abî Syuja'. These two books cover a lot of thahârah studies which are the main topics in this research. The next book that became the material for the study is Fiqih Taharah: Panduan Praktis Bersuci (Fiqh Taharah: A Practical Guide to Purification) by Ibn Abdullah; books in Indonesian which are considered representative in discussing thahârah. In accordance with Darmalaksana's opinion, the steps of this research analysis are (1) tracing primary and secondary sources, (2) analyzing data based on research formulas, (3) processing data/quoting references, (4) presenting data, (5) analyzing data, (6) interpreting the data, and (7) concluding. ${ }^{12}$ This type of research scenario was created by Darmalaksana specifically for literarary research.

\section{Thahârah Culture and the Effort to Prevent the Spread of Covid-19}

Thahârah is one of the commands of Allah Almighty that was first delivered to mankind at the beginning of the Prophet Muhammad's treatise as in surah al-Mudatstsir [74]: 4 which translates as "and your clothing purify". As important as this

${ }^{10}$ Ulber Silalahi, Metode Penelitian Sosial, (Bandung: Unpar press, 2006).

11 Wahyudin Darmalaksana, "Menulis Artikel Cepat Meskipun Tidak Suka Menulis," Kelas Menulis UIN Sunan Gunung Djati Bandung 1 (2020).

${ }^{12}$ Wahyudin Darmalaksana, Cara Menulis Proposal Penelitian, (Fakultas Ushuluddin UIN Sunan Gunung Djati Bandung, 2020). concept is, thahârah is always discussed at the beginning in the study of figh books. The word thahârah with its derivatives is repeated 31 times in the Quran. ${ }^{13}$ This indicates that thahârah is the key to worship.

Thahârah must be studied and understood by Muslims because it is a legal requirement for daily worship and is also a powerful way to maintain physical and non-physical cleanliness. In the Islamic concept, everything whether the body, clothes, and place must be cleaned of all dirt and impure things due to keeping things clean and pure is part of faith, at-thahûru syathrul îmân ${ }^{14}$. Islam pays great attention to cleanliness because being clean and holy is an effort to avoid contracting various germs or viruses. In addition, in al-Baqarah [2]: 222, it is stated that Allah Swt likes those who repent and those who keep them clean as He says:

They ask you about menstruation. Say: "It is an impurity. So, keep away from women during menstruation; and do not have intimacy with them until they are cleansed. But when they are cleansed, then go to them from where Allah has commanded you. Surely Allah loves those who are most repenting and loves those who keep themselves pure.

Seeing the importance of practicing thahârah in the real life for Muslims, it must be practiced. The meaning of culture (budaya) in this sense, according to The Great Indonesian Dictionary, is: thoughts, reason, results, and also something that has become a habit. Hence, the purpose of thahârah culture is an activity that is accustomed to the community in their daily life on a routine basis ${ }^{15}$. The thahârah activity is not only a ritual activity, but a habit that integrates with the Indonesian Muslim community, considering that this country is majority Muslim.

Thahârah is an activity to clean dirt and impurities that can be seen by the eye or not ${ }^{16}$

${ }^{13}$ Ahmad Mujahid, "THAHARAH LAHIR DAN BATIN DALAM AL-QURAN," Al-Risalah Jurnal Ilmu Syariah dan Hukum, vol.19, no. 2 (2019), p. 199.

${ }^{14}$ Hadis shahih yang diriwayatkan oleh Muslim. Ahmad Ali, Kitab Shahih Al Bukhari dan Muslim, Referensi hadis Sepanjang Masa dari Dua Ahli Hadis Paling Berpengaruh Dalam Dunia Muslim, (Jakarta, Alita Aksara Media, 2013), p. 87.

${ }^{15}$ https://kbbi.kemdikbud.go.id/entri/budaya "KBBI Daring," accessed January 5, 2020,

${ }^{16}$ Wahbah Az-Zuhaili, Al-Fiqh Islâm Wa Adillatuhu: Pengantar 
which the jurisprudence scholars call najîs' aini and najîs hukmî. ${ }^{17}$ Although it is not an object that is discussed, in terms of Sufism, thahârah means cleansing the soul from sins and bad behavior. In the context of maintaining cleanliness from various things that pollute the environment, thahârah is meant in the form of hissiyah, which is to clean yourself from various kinds of dirt that are visible to the eye. The procedure for cleaning and removing dirt is by using water or objects that have the same function as water. Meanwhile, in the context of maintaining non-physical cleanliness, the concept in question is thahârah ma'anâwiyah, which is the act of cleansing oneself from sinful acts such as eating things that are forbidden by Islam in the form of drinking alcohol and eating pork. ${ }^{18}$

There is no doubt that hundreds of hadith[s] are distributed in various narrations which state that Muslims must keep the environment clean. One of the hadith[s] that should be observed is the following.

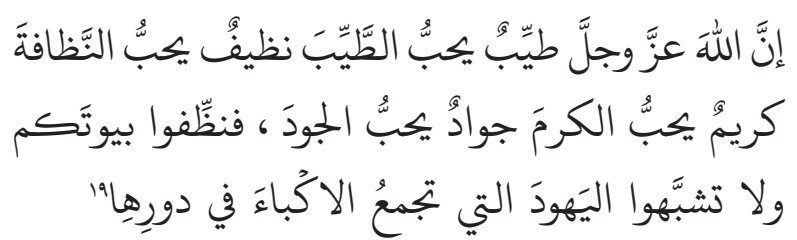
"Indeed, Allah is holy and loves holiness, Allah is clean and loves cleanliness, Allah is gracious and loves generosity. Therefore, clean your houses from various filth and do not be like the Jews who always collect dirty things in their homes".

Cleaning and removing dirt in Islam is obligatory. Apart from religious orders, maintaining cleanliness concerns the interests of many people. In this case, Islam pays great attention to cleanliness for all human beings, both physically and mentally clean. This means that Islam places great importance on cleanliness and human health throughout the ages to avoid various diseases.

Ilmu Fiqh, Tokoh-Tokoh Mazhab Figh, Niat, Thaharah, Shalat, 1 (Jakarta: Gema Insani, 2011), p. 202.

${ }^{17}$ As-sayid Sabiq, Fiqh As-Sunnah, (Cairo: Al-Fath li al-'Ilm al-Arabi, 2009).

${ }^{18}$ Ibnu Rusyd, "Tarjamah Bidayatul Mujtahid," Jilid II. Semarang: As-Syifa, (1990), p. 11.

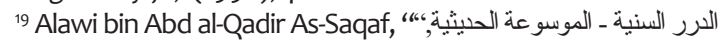
·r.r, https://dorar.net/hadith/search?skeys=\%D8\%A7\%D9\%84\%D9\%8 6\%D8\%B8\%D8\%A7\%D9\%81\%D8\%A9\%20\%D9\%85\%D9\%86\%20\%D8\%A7\%D9 \%84\%D8\%A5\%D9\%8A\%D9\%85\%D8\%A7\%D9\%86\&page $=2$.
The command to clean limbs, especially those that are open and actively carry out activities related to cleanliness and purity, as often as possible in order to prevent germs and dirt. This is based on the word of Allah in Surah al-Mudatstsir [74]: 4, "And purify your clothes" and also pay attention to the following Surah al-Baqarah [2]: 125.

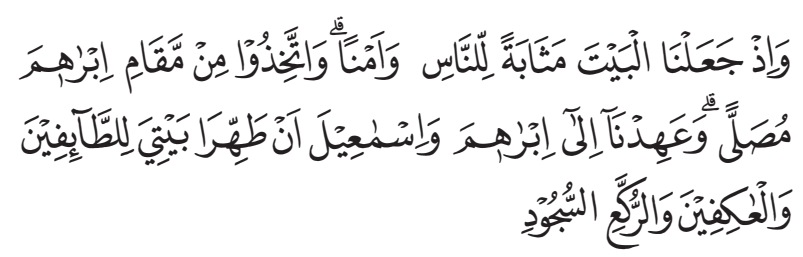

When We made the House (Ka'bah of Makkah) a frequented place for men, and a place of peace! Make from the Station of Ibrâhîm a place of prayer. We gave the (following directive) to Ibrähim and Ismā'il (Ishmael): "Purify My House for those who are to circumambulate (make Tawäf) and those who stay in I'tikâf, and those who bow down or prostrate themselves (in prayers).

The above arguments show that the command to clean dirt is very rational because it aims to ensure health. There is a research result which reports that people who do not understand how to behave cleanly are one of the causes of the spread of infectious diseases. ${ }^{20}$ Therefore, it is very appropriate if Islam attaches great importance to cleanliness and a clean life because it is a noble and praiseworthy act. Health experts often explain that the best way to treat viral diseases or other diseases is by maintaining cleanliness. This means that if the clean condition is always maintained, mankind will be protected from various diseases because in principle avoiding it is better than cure.

As Muslims who have a lot of guidance regarding the concept of thahârah or clean behavior, how should efforts be made to minimize the spread of Covid-19? As Indonesian Muslims, of course, we must follow the government's advice. In accordance with the Decree of the Minister of Health of the Republic of Indonesia number HK.01.07/MENKES/ 382/2020, all members of the community must maintain and apply health protocols to prevent transmission of Covid-19.

${ }^{20}$ Suci Musvita Ayu et al., "Peningkatan Kesehatan Melalui Perilaku Hidup Bersih Dan Sehat (PHBS) Sejak Dini Di Desa Hargomulyo Gedangsari Gunung Kidul," Jurnal Pemberdayaan: Publikasi Hasil Pengabdian Kepada Masyarakat,vol. 2, no. 1 (2018), pp. 20-27. 
These health protocols are (1) using a mask that covers the nose, mouth, and chin, (2) washing hands regularly with soap and running water or using an alcohol-based hand sanitizer, (3) maintaining a minimum distance of one meter from other people to avoid droplets of people who are coughing, sneezing and talking, and (4) increasing power endure the body by consuming balanced nutrition and exercising.

All these health protocols are actually in line with the teachings of Islamic jurisprudence. Islam has the concept of thahârah which is scientifically and medically very relevant to the health desired by the human body. It's just that Muslims need to get used to it in everyday life. Several offers that are worthy of being practiced and accustomed to in everyday life according to the perspective of Islamic figh are as follows.

\section{Using Water}

Water is the best means of washing and cleaning things. In Islam it is also stated that water is the best tool for purification. Hence, the scholars classify the types of water that are good for use. Muhammad bin Qasim al-Gâzi divided the water into three types, namely (1) absolute water, (2) water that has been used, and (3) unclean water. ${ }^{21}$ What is meant by absolute water is water that is holy and can also purify others. This type of water is rain water, sea water, well water, river water, spring water, snow water, and dew water. What is meant by water that has been used is water that is heated. This type of water is holy, but it cannot be used to purify other things. Meanwhile, unclean water is water that is less than two qullah and then contaminated with unclean. In this case, Wahbah az-Zuhaili as quoted by Muhajir gives a measurement that the two qullah [s] are equivalent to 270 liters of water or the size of $91.8 \mathrm{~cm} 2 .{ }^{22}$

Islamic teachings guide many types of clean water for purification. Rain water, for instance, is water that is absolutely pure and clean (AlAnfâl [8]: 11, al-Furqân [25]: 48). Sea water is also holy and clean to use, even the carcass is halal.

\footnotetext{
${ }^{21}$ Ibnu Qasim al-Gazi, Fath Al-Qarîb al-Mujîb..., p. 3

${ }^{22}$ Afifuddin Muhajir, "Fathul Qarib Al-Mujib," Al-Maktabah Al-Asíadiyyah, Situbondo, (2014), p. 10.
}

The kinds of water that have been mentioned are basically pure and clean unless it has been contaminated by an unclean thing so that it changes color, taste, and smell..$^{23}$

In the real life, Islam also guides Muslims to use running water for purification. The use of running water when purifying is in accordance with the explanation of the hadith of the Prophet Muhammad, the point of which is that we are told not to use still water to wash something. ${ }^{24}$ On the other hand, Muslims are prohibited from urinating in water that is still still because it has the potential to become unclean.

Water that is collected in a small container that is used or touched by an object that is soiled is not good for cleaning any dirt, but if the water is collected in a container that is large and even very large, if it is touched by something dirty amount a little so the water in the container is still safe from dirt, so it is good to use for cleaning dirt. Thus, cleaning and purifying any kind and form of dirt using running water is the best and most effective from both the perspective of health science and Islamic law/Figh.

\section{Taking Ritual Ablution and Washing Hand}

Ablution is a purification activity that is aimed at eliminating minor hadats by washing certain limbs with holy and purifying water accompanied by intention. The limbs that are washed according to Surah al-Mâidah [5]: 6 are (1) washing the face, (2) washing the hands up to the elbows, (3) rubbing the head, and (4) washing the feet to the ankles. The complete translation of the verses of the Quran is:

O you who believe! When you intend to offer As-Salat (the prayer), wash your faces and your hands (forearms) up to the elbows, rub (by passing wet hands over) your heads, and (wash) your feet up to ankles. If you are in a state of Janaba (i.e. had a sexual discharge), purify yourself (bathe your whole body). But if you are ill or on a journey or any of you comes from answering the call of nature, or you have been in contact with women (i.e.

${ }^{23}$ Al-Hafiz Ibnu Hajar Al-Asqalani, Bulughul Maram, (Pustaka Al-Kautsar, 2015), p. 9.

${ }^{24}$ Al-Hafiz Ibnu Hajar Al-Asqalani, Bulughul Maram..., p. 15. 
sexual intercourse) and you find no water, then perform Tayammum with clean earth and rub therewith your faces and hands. Allah does not want to place you in difficulty, but He wants to purify you, and to complete His Favour on you that you may be thankful.

The scholars differed regarding this verse. Majority revealed that ablution is ordered in conjunction with the obligation to pray five times a day and that it happened while in Mecca. Others argue that ablution was ordered before prayer. However, according to some others, ablution was only required after the Prophet Muhamamd moved to Medina. The reason is that the above verse shows the characteristics of the Madaniyah verse. This is the opinion of Imam Jalaluddin asSuyûtî in the book Asbâb an-Nuzûl. In a narration it is stated that Ayesha lost her necklace and the Prophet Muhammad her search for it. However, because it was nighttime, it was a little difficult to find the necklace until finally it was time for Fajr. When he woke up, Rasulullah PBUH rushed to offer prayers and look for ablution water, but Rasulullah did not find it. That is why this verse has come down which allows tayamum as a substitute for ablution if water is not found.

Regarding the loss of Ayesha's necklace, her father, Abu Bakr As-Siddiq, had scolded her and said that it was because of the necklace that it caused trouble because Muslims did not get water. However, when the verse was revealed, Abu Bakr praised Ayesha and considered her a blessing. According to As-Suyuthi, this is the strongest opinion. This was narrated by Imam Bukhari from Amr bin al-Harits from Abdurrahman bin al-Qasim. This hadith was also narrated by Imam at-Thabrani from Ubbad bin Abdillah bin Zubair who came from Aisyah. Wudhu is one of the main conditions for accepting the prayers of a Muslim. Allah does not accept prayers without being purified. " (Narrated by Muslim, 224). Your prayers are not accepted if you do not perform wudu. " (Narrated by Bukhari, 135 and Muslim, 225).

By doing ablution, actually someone has washed their hands effectively and removed the dirt on their hands. According to the Prophet's sunnah, one should interrupt the fingers and clean the palms of the hands with water before wudu begins. ${ }^{25}$ Apart from being of worship value, the activity of ablution is actually beneficial for health according to several scientific studies. According to the science of bacteria, if human skin is opened just $1 \mathrm{~cm}$, the skin will be infected by more than five million different bacteria. Each bacteria will grow so fast that the acid-base balance $(\mathrm{pH})$ in the skin will be disturbed. ${ }^{26}$ Meanwhile, the $\mathrm{pH}$ of the skin surface plays a very important role in protecting the body and limiting the development of germs (including the corona virus) which will cause disease. The skin is washed with ablution water, the $\mathrm{pH}$ will return to balance and the skin's moisture will return to normal.

Scientists examine the benefits and wonder of ablution for physical health. Fatah Yasin argued that apart from helping to get rid of minor sins, ablution can also affect human health. ${ }^{27}$ Performing ablution in the right way can prevent Muslims from various diseases. A general surgeon specialist and surgical oncology supersist from Cipto Mangunkusumo Hospital, named Bahar Azwar, said that the activity of ablution is to flush feces, dilute germs to reduce malignancy, and form regeneration of skin and mucous membranes ${ }^{28}$. With frequent washing during ablution, the body will not be susceptible to disease because the skin and mucous membranes which are the front for protection of the body can carry out their duties properly, namely destroying diseases that will eat away at the body.

One of the members of the body that plays a large role in daily activities is the palm of the hand. The palm of the hand is a tool used to drain water to all members of ablution and is used to rub or rub other members of the ablution. However, the palm of the hand is also a tool used to hold everything we desire. Therefore, it is possible that it will be contaminated by microorganisms or germs.

\footnotetext{
${ }^{25}$ Ibnu Qasim al-Gazi, Fath Al-Qarîb al-Mujîb..., p. 6.

${ }^{26}$ Muhammad Akrom, Terapi Wudhu, (Mutiara Media, 2010), p. 113.

27 Qurrotul Aien Fatah Yasin, "Physical And Spiritual Miracles Of Muslims' Ablution," QURANICA-International Journal of Quranic Research, vol. 3, no. 2 (2012), pp. 67-83.

${ }^{28}$ Bahar Azwar, Fikih Kesehatan; Dari Ibadah, Pengobatan, Sampai Penyakit Flu Burung, (Jakarta: Quantum Media, 2005), p. 9.
} 
Before Covid-19 broke out throughout the world which required us to diligently wash our hands, the results of research from the Center of Disease Control (CDC) revealed that flu, worms, typhus, and diarrhea were diseases that very often occurred due to negligent hand washing. ${ }^{29}$ Research conducted by the Great Lakes Recruits Command Center of the United States Navy in Illinois also reports that regular hand washing can slow the spread of cold viruses and other infections. For this reason, the Holy Prophet gave an example for us to wash our palms three times and rub between our fingers so that we are clean from dirt, viruses, and bacteria that stick to our hands.

Seeing some of the research results above, ablution is the most effective way to wash hands even without soap. If Muslims realize how tremendous the benefits of ablution are in the midst of the Covid-19 epidemic and get used to it as a way to purify even though it is not for the purpose of prayer, this activity of ablution can be an effort to prevent the spread of Covid 19.

Another extinction in ablution is istinsyaq or inhaling water into the nasal cavity and istintsâr or spraying it by pushing the water with tight air pressure. According to dr. Bagus Wicaksono Sp THT from RSIA Kemang, Medical Care as reported in detik.Healt (5/15/2019), this activity can help wash all germs, allergies, dust, bacteria, or viruses from the nose as long as it is done according to the Prophet's recommendation, that is, to the back of the nasal cavity ${ }^{30}$. Wicaksono added that if in each wudhu for the five prayers we perform istinsyaq three times, in one day we have cleaned the nasal cavity from germs 15 times. This means that the cleanliness and cleanliness of the nasal cavity is maintained and can be protected from various respiratory diseases such as flu and Acute Respiratory Infections (Saluran Pernapasan Akut=ISPA). Research conducted by Ghonanim also states that washing the nose during ablution can reduce $S$. aureus nasal colonization and serious

29 Imam Musbikin, Whudu Sebagai Terapi, (Yokyakarta: Nusa Media, 2009), p. 94.

${ }^{30}$ Widiya Wiyanti, "Ini Manfaat Istinsyaq, Menghirup Air ke Rongga Hidung Saat Wudhu," detikHealth, accessed January 6, 2020, https://health.detik.com/berita-detikhealth/d-4550633/inimanfaat-istinsyaq-menghirup-air-ke-rongga-hidung-saat-wudhu. staphylococcal disease ${ }^{31}$. This can be a simple, easy and effective way. In other words, istinsyaq done correctly is also an effort to prevent the transmission of Covid-19.

Apart from a series of ablution activities, washing hands is a very good thing to prevent the spread of viruses that stick to hands, especially washing hands accompanied by soap as campaigned by the Covid-19 response task force in Indonesia. In addition, the government also recommends the use of a handsanitizer in washing hands so that the bacteria that sticks to the hands really die.

Every day, our hands do a lot of activities that we realize or not, from waking up to going to sleep again. For this reason, it is suspected that our hands touch a lot of dirty things that are contaminated with bacteria in the Covid-19 pandemic season. Therefore, hands are the first and foremost part of the body that must be cleaned and washed using clean and running water and using soap. Washing hands is actually something that was used by the Prophet Muhammad as written in a hadith as follows. ${ }^{32}$

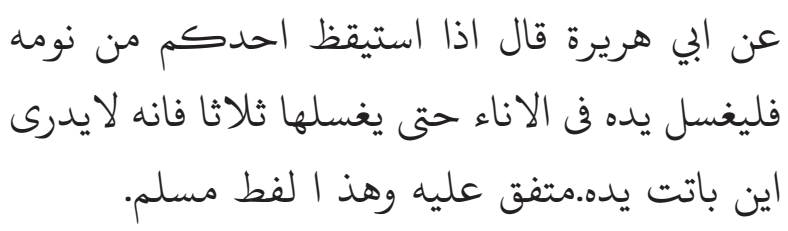

"From Abi Hurairah Prophet Muhammad PBUH said: If any of you wake up from sleep, please wash your hands three times before throwing them into a container of water because no one knows where and what the hands do while sleeping".

Washing hands is an almost mandatory command when just getting up from sleep according to the agreement of the scholars. ${ }^{33}$ This is based on the hadith of the Prophet Muhammad as follows. ${ }^{34}$

كانَ رسولُ اللهِ صلَّى اللهُ علَيهِ وسلَّمَ إذا أرادَ أن ينامَ،

${ }^{31}$ Mabrouk Mahmoud Ghonaim and Rawhia Hassan El-Edel, "Effect of the Muslims' Ablution Practice on Nasal Colonization of Staphylococcus Aureus.," Ibnosina Journal of Medicine \& Biomedical Sciences, vol. 8, no. 5 (2016).

${ }^{32}$ Al-Hafiz Ibnu Hajar Al-Asqalani, Bulughul Maram..., p. 59.

33 Yusuf Al Qaradhawi, Fatwa-Fatwa Kontemporer 3, (Jakarta: Gema Insani, 1995), 123.

34 As-Saqaf, “الدرر السنية ـ الموسوعة الحديثية." 


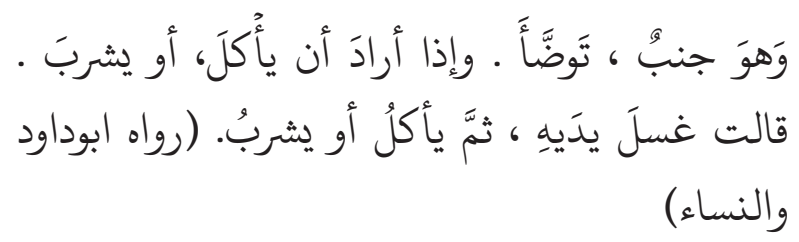

"If the Messenger of God wanted to sleep, while he was junub, he would perform ablution. And if he wanted to eat or drink, she said: He washed his hands, then eats or drink"

According to the Hanafi and Maliki schools of thought, it is obligatory to wash the cracks of the fingers and the open parts that are under the long nails covering the tips of the fingers. Likewise, removing the dirt inside the nails is mandatory. ${ }^{35}$ Furthermore, Jumhur Ulama revealed that those who wear the narrow ring on the finger must be cleaned so that the dirt under the ring can be removed.

From the description above it can be underlined that cleaning and purifying hands from all impurities is obligatory. If it is related to the current condition of the Covid-19 pandemic, washing hands for people who leave the house can be punished as compulsory on the grounds of preventing the appearance of fade (li sad az-zarâ'i or preventive action). This is because bacteria and viruses that stick to the hands cannot be seen for real.

\section{Consuming Halâl and Thayyib Foods}

In Islamic jurisprudence, the description of the thahârah chapter is about the halal and forbidden food and drink which is referred to by the book Fath al-Qarîb al-Mujîb with the term. Why is the consumption of food and drink an important topic in the chapter thahârah? This is because the cleanliness of a Muslim does not only require cleanness and purity that is outside the body, but also demands that which is inside the human body.

Due to the Covid-19 prevention health protocol, food consumption is an important thing to pay attention to. The government urges that all citizens should consume nutrition and healthy food $^{36}$. Thousands of years ago, Islam has urged Muslims to eat halal and nutritious food (thayyib)

35 Wahbah Az-Zuhaili, Al-Figh Islâm Wa Adillatuhu..., p. 308.

36 "SE_MENDAGRI_PENCEGAHAN_PENYEBARAN COVID-19_pdf.Pdf." as Allah says in Surah al-Baqarah [2]: 168:

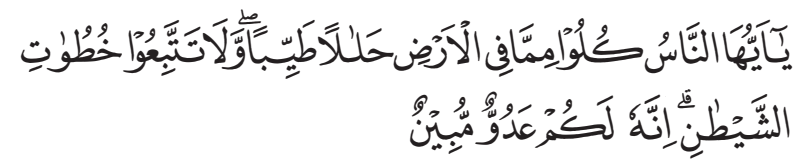

"O mankind! Eat of that which is lawful and clean on earth, and do not follow the footsteps of Shaitan (Satan) Verily, he is to you an open enemy".

What is meant by halâl food in the perspective of Islam is food that is halâl because of its existence and halal because of how to obtain it by illegal means such as the result of stealing and the result of cheating. Food that is not halâl (illegal food) because of its substances such as pork, carcass, and blood as written in al-Maidah [5]: 3 is clearly prohibited in Islam.

"Prohibited to you are dead animals, blood, the flesh of swine, and that which has been dedicated to other than Allah, and [those animals] killed by strangling or by a violent blow or by a head-long fall or by the goring of horns, and those from which a wild animal has eaten, except what you [are able to] slaughter [before its death], and those which are sacrificed on stone altars, and [prohibited is] that you seek decision through divining arrows. That is grave disobedience. This day those who disbelieve have despaired of [defeating] your religion; so fear them not, but fear Me. This day I have perfected for you your religion and completed My favor upon you and have approved for you Islam as religion. But whoever is forced by severe hunger with no inclination to sin then indeed, Allah is Forgiving and Merciful"

Food that is beneficial for humans can be in the form of plants and animals. Of the various types of food, some cause disease and some are healthy. ${ }^{37}$ Among the unhealthy foods is raw, uncooked meat. Head of the Indonesian Ministry of Health's Emerging Infectious Diseases Sub-directorate, Endang Budi Hastuti, said that to prevent Covid-19 infection, people must avoid consuming raw meat because it can cause human immunity to become weak. ${ }^{38}$ In the view of Islam, raw meat is not included in the thayyib

\footnotetext{
37 Muhammad Kamil Abdushshamad, Mukjizat Ilmiah Dalam Al-Qur'an, Transl," Alimin, Dkk, (Jakarta: Akbar, 2004), p. 235.

${ }^{38}$ https://www.jpnn.com/news/cegah-tertular-virus-coronahindari-konsumsi-daging-mentah “JPNN," October 31, 2020,.
} 
meaningful category of food. However, food can be categorized as food which is thayyib for the body, is food that is cooked and which does not have a bad effect on human health.

Foods and drinks that have a positive impact on the body are halâl and thayyib foods and drinks. Foods that are forbidden because of their existence and forbidden for other reasons as described above must absolutely be avoided. Likewise, we must avoid food that is contaminated by dirty objects that are thought to contain viruses that are harmful to the body. The attention of Islamic teachings to health is very high. In the perspective of ushul figh, Islam forbids and punishes major sins for the perpetrators who eat illegal goods and also for those who mediate them. ${ }^{39}$

Complying with the protocol guidelines for preventing the spread of the Covid-19 virus as recommended by the government is a form of obedience to Allah and His Messenger. Surah alNisâ [4]: 59 very emphatically explains that we are obliged to follow the orders of Allah Swt, His Messenger, and also ulil amri or the government. As a member of society of a sovereign state, following the recommendations and regulations of the government is an obligation. On the other hand, disregarding the government's recommendation means that in addition to ignoring government orders, Allah Swt and Prophet Muhammad to deny orders. This government policy is made through deep thought because it involves the lives of many people.

Government recommendations regarding health protocols in preventing the spread of Covid-19 are very closely related to the safety of people's lives. The recommendation to carry out health protocols in order to prevent the spread of diseases such as Covid-19 which is currently endemic is an obligation for everyone who lives in Indonesia. In connection with the Covid-19 outbreak that has hit our country, people should be prohibited from leaving Indonesia as the Prophet Muhammad said which prohibits someone from entering and leaving a country due to an outbreak of infectious diseases. ${ }^{40}$

\footnotetext{
${ }^{39}$ Yusuf Al Qaradhawi, Fatwa-Fatwa Kontemporer 3..., p. 838.
} ${ }^{40}$ Al-Hafiz Ibnu Hajar Al-Asqalani, Bulughul Maram..., p. 89.

\section{Conclusion}

Maintaining health by (1) adhering to health protocol guidelines, (2) washing hands using running water, (3) maintaining distance from people, and (4) maintaining body immunity by eating good food when the Covid-19 pandemic hits this country is an action which is in accordance with Islamic law regarding the concept of thahârah. In this concept, it is explained that the cleanliness and purity of all members of the body, residence, and clothing are part of the legal requirements of worship that must be noticed.

The series of concepts of thahârah are also eating nutritious foods that are suitable for the body and avoiding eating raw foods. These are all actions in the context of carrying out the orders of Islamic law. Consuming food and drinking halâl and tayyib drinks is also an effort to keep our stamina from a very dangerous disease or virus such as Covid-19.

\section{References}

Abdullah, Ibnu, Fiqih Thaharah: Panduan Praktis Bersuci. Pustaka Media, 2018.

Abdushshamad, Muhammad Kamil, Mukjizat Ilmiah Dalam Quran, Trans. Alimin, Dkk, Jakarta: Akbar, 2004.

Ahmad, Mohammad Shodiq, "Thaharah: Makna Zawahir Dan Bawathin Dalam Bersuci (Perspektif Studi Islam Komprehensif," Mizan: Journal of Islamic Law, vol. 2, no. 1, 2014. https://doi.org/10.32507/mizan.v2i1.134. Akrom, Muhammad, Terapi Wudhu, Mutiara Media, 2010.

Asqalani, Al-Hafiz Ibnu Hajar Al-,, Bulughul Maram, Pustaka Al-Kautsar, 2015.

Ayu, Suci Musvita, Arif Kurniawan, Ainul Yaqin Ahsan, and Achmad Khoirul Anam. "Peningkatan Kesehatan Melalui Perilaku Hidup Bersih Dan Sehat (PHBS) Sejak Dini Di Desa Hargomulyo Gedangsari Gunung Kidul." Jurnal Pemberdayaan: Publikasi Hasil Pengabdian Kepada Masyarakat, vol. 2, no. 1, 2018.

Azwar, Bahar, Fikih Kesehatan; Dari Ibadah, Pengobatan, Sampai Penyakit Flu Burung,. Jakarta: Quantum Media, 2005.

Darmalaksana, Wahyudin. Cara Menulis Proposal 
Penelitian. Fakultas Ushuluddin UIN Sunan Gunung Djati Bandung, 2020.

__, "Menulis Artikel Cepat Meskipun Tidak Suka Menulis." Kelas Menulis UIN Sunan Gunung Djati Bandung 1 (2020).

Gazi, Ibnu Qasim al-, Fath Al-Qarîb al-Mujîb, Egypt: Musthafa al-Bab al-Halabi, 1925.

Ghonaim, Mabrouk Mahmoud, and Rawhia Hassan El-Edel, "Effect of the Muslims' Ablution Practice on Nasal Colonization of Staphylococcus Aureus." Ibnosina Journal of Medicine \& Biomedical Sciences, vol. 8, no. 5, 2016.

https://kbbi.kemdikbud.go.id/entri/budaya " KBBI

Daring," accessed January 5, 2020,

https://www.jpnn.com/news/cegah-tertular-viruscorona-hindari-konsumsi-daging-mentah.

“JPNN," October 31, 2020.

Mughniyah, Muhammad Jawad, Fiqih Lima Mazhab: Ja 'fari, Hanafi, Maliki, Syafi 'i, Hambali (Gold Edition), Shaf, 2015.

Muhajir, Afifuddin, Fathul Qarib Al-Mujib, AlMaktabah Al-Asíadiyyah, Situbondo, 2014.

Mujahid, Ahmad. "THAHARAH LAHIR DAN BATIN

DALAM AL-QURAN." Al-Risalah Jurnal Ilmu Syariah dan Hukum, vol.19, no. 2, 2019.

Musbikin, Imam, Whudu Sebagai Terapi, Yokyakarta: Nusa Media, 2009.

Qaradhawi, Yusuf Al-, Fatwa-Fatwa Kontemporer 3. Jakarta: Gema Insani, 1995.

Rusyd, Ibnu, Tarjamah Bidayatul Mujtahid, Jilid II. Semarang: As-Syifa, 1990.

Sabiq, sayid As-, Figh As-Sunnah, Cairo: Al-Fath li al-'llm al-Arabi, 2009.

Saqaf, Alawi bin Abd al-Qadir, As-, الدرر السنية - الموسوعة "الحديثية keys=\%D8\%A7\%D9\%84\%D9\%86\%D8\%B8\%D8\%A7 \%D9\%81\%D8\%A9\%20\%D9\%85\%D9\%86\%20\%D8\%A 7\%D9\%84\%D8\%A5\%D9\%8A\%D9\%85\%D8\%A7\%D9 $\% 86 \&$ page $=2$.
Google Docs. "SE_MENDAGRI_PENCEGAHAN PENYEBARAN_COVID-19_pdf.Pdf." accessed October 21, 2020. https://drive.google.com/ file/d/1Ev_3qrgeA8i1k6iF-zAKnFs4MHBtvULX/ preview?usp=embed_facebook.

Silalahi, Ulber, Metode Penelitian Sosial. Bandung: Unpar press, 2006.

Telaumbanua, Dalinama, "Urgensi Pembentukan Aturan Terkait Pencegahan Covid-19 di Indonesia." QALAMUNA: Jurnal Pendidikan, Sosial, dan Agama, vol. 12, no. 01, March 21, 2020. https://doi.org/10.37680/qalamuna. v12i01.290.

Tiara, Rahmah Al, “Antisipasi Covid-19, Pemko Pariaman Gelar Program Thaharah - Portal Berita Editor." accessed October 12, 2020. http://www.portalberitaeditor.com/antisipasicovid-19-pemko-pariaman-gelar-programthaharah/.

Wiyanti, Widiya, "Ini Manfaat Istinsyaq, Menghirup Air ke Rongga Hidung Saat Wudhu." detikHealth. accessed January 6, 2021. https://health.detik.com/beritadetikhealth/d-4550633/ini-manfaat-istinsyaqmenghirup-air-ke-rongga-hidung-saat-wudhu.

Yasin, Qurrotul Aien Fatah, "Physical And Spiritual Miracles Of Muslims' Ablution." QURANICAInternational Journal of Quranic Research, vol. 3, no. 2, 2012.

Yuliantina, Anastasia lilin, "Tak Bisa Ditawar, Yuk Mencegah Dan Menekan Penyebaran Virus Corona Dengan 3M." accessed October 21, 2020. https://kesehatan.kontan.co.id/news/ tak-bisa-ditawar-yuk-mencegah-dan-menekanpenyebaran-virus-corona-dengan-3m.

Zuhaili, Wahbah Az-, Al-Fiqh Islâm Wa Adillatuhu :Pengantar Ilmu Figh, Tokoh-Tokoh Mazhab Fiqh, Niat, Thaharah, Shalat. 1, Jakarta: Gema Insani, 2011. 